INTERACTION:Jurnal Pendidikan Bahasa: Vol. 6, No. 2: Oktober 2019

ISSN: 2406-9558; E-ISSN: 2406-9566

\title{
The Students' Ability on Comparison Degree in Irregular Form
}

\author{
Siti Nur Fatimah Hud \\ sitinurfatimahud@gmail.com \\ MA Muhammadiyah Aimas
}

\section{ABSTRACT}

The study is designed to investigate the students' ability in using comparison degree on learning English especially in using irregular forms. To look their understanding about this matery the writer used method design descriptive design. Comparison degree was a compare between noun, people, and animal. Comparison degree has three type that was positive degree, comparative degree, and superlative degree. In take the data of this study, the writer especially in take data of comparative degree and superlative degree but just irregular forms. The sampling of data, the writer choose the students of the first grade at Madrasah Aliyah Muhammadiyah Aimas of number 20 person. The writer used written test as tools to take the data that was multiple-choise of number eighteen comparative degree and seventeen to superlative degree. Before doing research, the writer explains about comparison degree in irregular forms to the students and then the writer given test about comparative degree in irregular forms to the students. First step done the author was giving material of paper to students about comparison degree in irregular form and both steps given the students exercise about matery had given as multiple-choice. After that, exercise correct and analyze. By this test given by the author getting the data for her research. From 12 students of first grade at Madrasah Aliyah Muhammadiyah Aimas got score, to comparative degree in worse $=69 \%$, better $=62 \%$, farther $=85 \%$, less $=69 \%$, more $=96 \%$, elder $=7,7 \%$. Commonly, their ability can be seen based on the score of test, in which they got their mean of score of test was $47 \%$. The writer can explain that the students of the first grade at Madrasah Aliyah Muhammadiyah Aimas yet understand about comparative degree, their ability was still including in bad category, and superlative degree specifically on worst $=65 \%$, best $=50 \%$, farthest $=23 \%$, least $=$ $8 \%$, most $=31 \%$, Eldest $=89 \%$. In overall, can be seen their mean score of superlative degree $=32 \%$. It means that their ability in superlative degree was very bad. By this result, the writer found that the students understanding on superlative degree was still very minus.

Keywords: Comparison Degree, Irregular form 
INTERACTION:Jurnal Pendidikan Bahasa: Vol. 6, No. 2: Oktober 2019

ISSN: 2406-9558; E-ISSN: 2406-9566

\section{INTRODUCTION}

English is one of the international languages that is used by many people in the world and in many areas of everyday life. Therefore, using English is the easiest way to communicate with people from other countries about many aspects in human life such as technology, economy, social, and politics. For Indonesia, English is a foreign language. Learning a foreign language is an integrated process that the learner should study the four basic skills: listening, speaking, reading, and writing. We use it to understand our world through listening and reading and to communicate our feeling, need, and desires through speaking and writing. And also there are three basic language components such as phonology, grammar, and vocabulary. Grammar is one of the language components which has an essential role in language learning. The mastery will help students in communication because they at least know how to construct sentence correctly.

In era-globalization progressively to advance in seiringnya development period, influence quality of education in learning foreign language. According to Morris (1981: 347), Degree is one of the form used in the comparison of adjective and adverb. He also states that comparison is the modification or inflection of an adjective or adverb to denote the three degrees (positive, comparison, and superlative) 1981:271. Comparison degree is a comparative between two words that different used to animals or noun. Comparison degree is degrees or stages or levels of comparing something or someone with something or someone else. Among the kinds of english grammar, comparison degree is one of the aspects that should be mastered well. Comparison degree have a function to compare two or more things in life, so that it is important for students to learn this. The comparison is signaled in english by the suffix-er or by a word of comparative (bad, good, far, little, many, and old) and the conjuction- or preposition- like word as or than.

Comparison is a name in given to grammar by using to comparison two, animals, noun, or etc. Comparison are the second degree of comparison on adjective from adverb. Irregular form on comparative degree has definite words. There are some adjective have irregular form. For example comparative degree in irregular adjective. Bad - Worse- Worst, Far-Further-Furthest, Good- Better- Best, Little-Less-Least, Many, Much, Some-More-Most.

As we can see above that those comparison degree in irregular have the differrent form of the possitive form, different with the comparison degree in reguler form that we only need put the suffix er, and est or more and the most to make the comparative and the superlative degree. 
INTERACTION:Jurnal Pendidikan Bahasa: Vol. 6, No. 2: Oktober 2019

ISSN: 2406-9558; E-ISSN: 2406-9566

\section{LITERATURE REVIEW}

\section{Previous of Study}

Ari Susanti (2011), with the title research was an analysis on students' mastery of degree comparison (case study at second gray VIII 10) of SMP Negeri 3 tangerang selatan. The clause consits of 38 students in research she applied two techniques in collecting data they were test and interview. Based on the result of the case study conducted at the school grade of SMP N 3 Tangerang selatan (class VIII. 10) academic year 2010/2011, the writer conclude that there are 5 reasons that students find difficulties in mastering degrees of comparison : they are confused to put suffixer for comparative and -st/est for superlative or prefix more for comparative and most for superlative, they forgot to add the article the in the superlative form and confused to omit or misplaced the use of be, they forgot to add than adjective for comparative form, they did not know how to change the word that was ended in $-\mathrm{y}$ to $-\mathrm{i}$ and add er/est, and some students confused to differentiate the usage of comparative or superlative degree.

The different of this research with her research were: the writer's was foccused on comparison degree in irregular form (bad, good, far, many, little, and old) while her research was focused on comparison degree in regular form.

Fatmawati (2010), with the title of her research was "The analysis on students' difficulies in learning degrees of comparison. The sample of the research was 36 students of second year of SMP Dua Mei Ciputat. The test was about comparative and superlative degree and it was consists of 30 items such as 10 items for comparative, 10 items for superlative, and 10 items for the usage of comparative and superlative degree. According to the data of the test result, it was obtained that there were $76,11 \%$ who had the difficulties in the item of comparative form, $65 \%$ in the form of superlative and $87,77 \%$ in the items of the usage of both comparative and superlative degree. It was mean that most students had the difficulties in distinguising the usage of comparative and superlative forms.

The research that had done by Fatmawati had the different aim of the writer's, her research aimed to analyze the students difficulties in learning degrees of comparison, while the writer's aimed was to see how far was the students ability on comparison degree in irreguler with amount the sample was 12 students.

Fernando (2010), had done his research with the title 'improving students ability in forming degree of comparison by using subtitition drills (A classroom action research at the first grade of accountancy class at vocational school of bangun nusantara 2, cipondoh, tangerang)'. The subject of this study was the students of $\mathrm{X}$ accountancy class at vocatuonal school of Bangun Nusantara 2, Cipondoh, Tangerang in which the 
class cinsist of 33 students. Based on the result, there were 32 from 33 students or $96,97 \%$ of their score had passed the minimal mastery level criteria with the total mean score 84,90 . It improved $24,24 \%$ from posttest 1 which gains $72,73 \%$ with the total mean score 77,12 . It also improved 51,52\% from pretest to posttest 2 which gain only $45,45 \%$ with the total mean score 68,18 . The writer concluded that substitution drills can improve the students ability in learning degrees of comparison at the first grade of accountant class at vocational school of bangun nusantara 2 Cipondoh, Tangerang and Classroom Action Research could be called success because it has gained the target.

The research by Fernando has the same discussion that was in comparison degree but his research was a classroom action research with the aim of his research was to know whether students' understanding in English grammar especially in degrees of comparison could be improved by using subtitution drills technique or not.

\section{METHOD}

\section{Design}

This research used a descriptive method in order to describe the students' ability on comparison degree in irregular forms at The First Grade of Madrasah Aliyah Muhammadiyah Aimas, the data gotten were analyzed and included in some criterias. Descriptive quantitative is a methode to take data in numeral form. By this method, the writer got her data.

\section{Analysis Data}

Data analysis is the process of arranging the data sequence categorize it into a pattern, category and description of the base. After collected the data, the next process done by the researcher was how to analyzed the data has gotten. The result of score test in using comparison degree in irregular form then analyzed by scoring then finding the mean of score. In scoring the data, the writer used as the following formula: Score $=\mathrm{F}$ x $100 \%$

$\mathbf{N}$

In which:

$\mathbf{F} \quad=$ The Total Gain

$\mathbf{N}=$ Total Score

After doing the estimation, the writer can got the data to be analyzed to see whether the students had been able or not in understanding the used of comparison degree in irregular form. 


\section{RESULT AND DISCUSSION}

\section{Findings}

In which the research question was how were the students ability on comparison degree in irregular form at the first grade of Madrasah Aliyah Muhammad Aimas?

To answer the question, the researcher needed to explain her methode of data collection.

1. The writer prepare material about comparison degree in irregular form then given to the students.

2. The writer prepare test about comparison degree in irregular form to be given to the students by make a sentence used comparison degree in irregular form and answer the multiple-choise.

3. After getting the data and than done tabulation of data.

\section{The result of tabulated data in comparison degree}

Based on the given test that consist of three items for each of irregular adjective in comparison degree. The researcher got the following score or category. The category was result of the formula $\mathrm{x}-100 \%$.

\section{List of the result of comparison degree}

\begin{tabular}{|c|c|c|c|c|c|c|c|c|}
\hline \multirow{2}{*}{ No. } & \multirow{2}{*}{$\begin{array}{l}\text { Name Of } \\
\text { Students }\end{array}$} & \multicolumn{6}{|c|}{ Comparative Degree } & \multirow{2}{*}{$\begin{array}{c}\text { Score } \\
\text { of } \\
\text { Test }\end{array}$} \\
\hline & & Worse & Better & Farther & Less & More & Elder & \\
\hline 1. & $\begin{array}{c}\text { Student } \\
\text { A }\end{array}$ & 3 & 3 & 3 & 2 & 2 & 2 & 83 \\
\hline 2. & Student B & 2 & 1 & 2 & 1 & 3 & 0 & 50 \\
\hline 3. & $\begin{array}{l}\text { Student } \\
\text { C }\end{array}$ & 2 & 1 & 1 & 2 & 2 & $\mathbf{0}$ & 44 \\
\hline 4. & $\begin{array}{c}\text { Student } \\
\text { D }\end{array}$ & 3 & 2 & 2 & 2 & 3 & 0 & 67 \\
\hline 5. & Student E & $\mathbf{0}$ & 2 & 1 & 1 & 2 & $\mathbf{0}$ & 33 \\
\hline 6. & Student F & 2 & 1 & 3 & 3 & 2 & $\mathbf{0}$ & 61 \\
\hline 7. & $\begin{array}{c}\text { Student } \\
\text { G }\end{array}$ & 2 & 1 & 2 & 2 & 2 & $\mathbf{0}$ & 50 \\
\hline 8. & $\begin{array}{c}\text { Student } \\
\text { H }\end{array}$ & $\mathbf{0}$ & $\mathbf{0}$ & 1 & 1 & 1 & $\mathbf{0}$ & 17 \\
\hline 9. & Student I & $\mathbf{0}$ & 1 & 2 & $\mathbf{0}$ & 1 & 0 & 22 \\
\hline 10. & Student J & $\mathbf{0}$ & 2 & 1 & 1 & 2 & $\mathbf{0}$ & 33 \\
\hline
\end{tabular}


INTERACTION:Jurnal Pendidikan Bahasa: Vol. 6, No. 2: Oktober 2019

\begin{tabular}{|r|l|l|l|l|l|l|l|l|}
\hline 11. & Student $\mathrm{K}$ & 2 & 1 & 2 & 2 & 2 & 0 & 50 \\
\hline 12. & Student L & 2 & 1 & 2 & 1 & 3 & 0 & 50 \\
\hline
\end{tabular}

On table above, the score 0-3 it shows the amount of the test that they answered correctly.

\begin{tabular}{|c|c|c|c|c|c|c|c|c|}
\hline \multirow{2}{*}{ No. } & \multirow{2}{*}{$\begin{array}{l}\text { Name Of } \\
\text { Students }\end{array}$} & \multicolumn{6}{|c|}{ Superlative Degree } & \multirow{2}{*}{$\begin{array}{c}\text { Score } \\
\text { of } \\
\text { Test }\end{array}$} \\
\hline & & Worst & Best & Farthest & Least & Most & Eldest & \\
\hline 1. & Student A & 3 & 1 & 0 & 0 & 0 & 2 & 33 \\
\hline 2. & Student B & 3 & 1 & 0 & 0 & 0 & 2 & 33 \\
\hline 3. & Student C & 1 & 0 & 0 & 0 & 0 & 2 & 17 \\
\hline 4. & Student D & 0 & 0 & 0 & 0 & 0 & 2 & 11 \\
\hline 5. & Student E & 1 & 3 & 1 & 0 & 2 & 1 & 44 \\
\hline 6. & Student F & 1 & 0 & 0 & 0 & 0 & 2 & 17 \\
\hline 7. & Student G & 1 & 0 & 0 & 0 & 0 & 2 & 17 \\
\hline 8. & Student $\mathrm{H}$ & 0 & 3 & 2 & 0 & 0 & 3 & 44 \\
\hline 9. & Student I & 2 & 0 & 0 & 0 & 1 & 2 & 28 \\
\hline 10. & Student J & 1 & 3 & 1 & 0 & 2 & 2 & 50 \\
\hline 11. & Student K & 1 & 0 & 0 & 0 & 0 & 2 & 17 \\
\hline 12. & Student L & 3 & 2 & 2 & 2 & 3 & 1 & 72 \\
\hline
\end{tabular}

The explanation of the table above that the writer had given them a written test with total number of test was consists of thirty six numbers in which each point of comparative and superlative degree consists of three questions. The point 0-3 as in the table above are meant the amount of correct answer.

\section{Discussion of The Research}

In this discussion of the reasearch, the reasercher would like to explain about mean of score got the students by test comparison degree in irregular form in which the writer categories their score in the following category: 
INTERACTION:Jurnal Pendidikan Bahasa: Vol. 6, No. 2: Oktober 2019

\begin{tabular}{|c|c|c|}
\hline No & Score & Category \\
\hline 1. & $96-100$ & Excellent \\
\hline 2. & $90-95$ & Very Good \\
\hline 3. & $86-89$ & Good \\
\hline 4. & $70-85$ & Faily Good \\
\hline 5. & $60-69$ & Enough \\
\hline 6. & $40-59$ & Bad \\
\hline 7. & $0-39$ & Very Bad \\
\hline
\end{tabular}

To see more detail about the students ability, the writer had scoring the students ability on comparison degree as the following table:

Table I. The final score of comparative degree by tabulation mean.

\begin{tabular}{|l|l|c|c|c|c|c|c|c|}
\hline \multirow{2}{*}{ No. } & \multirow{2}{*}{$\begin{array}{l}\text { Name Of } \\
\text { Students }\end{array}$} & \multicolumn{5}{|c|}{ Comparative Degree } & \multirow{2}{*}{$\begin{array}{c}\text { Score } \\
\text { of } \\
\text { Test }\end{array}$} \\
\cline { 3 - 10 } & & Worse & Better & Farther & Less & More & Elder & \\
\hline 1. & Student A & 3 & 3 & 3 & 2 & 2 & 2 & 83 \\
\hline 2. & Student B & 2 & 1 & 2 & 1 & 3 & 0 & 50 \\
\hline 3. & Student C & 2 & 1 & 1 & 2 & 2 & 0 & 44 \\
\hline 4. & Student D & 3 & 2 & 2 & 2 & 3 & 0 & 67 \\
\hline 5. & Student E & 0 & 2 & 1 & 1 & 2 & 0 & 33 \\
\hline 6. & Student F & 2 & 1 & 3 & 3 & 2 & 0 & 61 \\
\hline 7. & Student G & 2 & 1 & 2 & 2 & 2 & 0 & 50 \\
\hline 8. & Student H & 0 & 0 & 1 & 1 & 1 & 0 & 17 \\
\hline 9. & Student I & 0 & 1 & 2 & 0 & 1 & 0 & 22 \\
\hline 10. & Student J & 0 & 2 & 1 & 1 & 2 & 0 & 33 \\
\hline 11. & Student K & 2 & 1 & 2 & 2 & 2 & 0 & 50 \\
\hline 12. & Student L & 2 & 1 & 2 & 1 & 3 & 0 & 50 \\
\hline
\end{tabular}


INTERACTION:Jurnal Pendidikan Bahasa: Vol. 6, No. 2: Oktober 2019

ISSN: 2406-9558; E-ISSN: 2406-9566

\begin{tabular}{|c|c|c|c|c|c|c|c|}
\hline $\begin{array}{c}\text { Score of } \\
\text { Comparative } \\
\text { Degree }\end{array}$ & $69 \%$ & $62 \%$ & $85 \%$ & $69 \%$ & $96 \%$ & $7,7 \%$ & $47 \%$ \\
\hline
\end{tabular}

Based on the table above, can be seen from 36 questions in multiple choise in which consists of three question related with worse, better, farther, less, more, elder (comparative degree) and worst, best, farthest, least, most, eldest (superlative degree) with amount of the students were twelve students.

Then calculated in overall their ability was $47 \%$ on comparative degree. It was included in bad criteria.

Table II. The final score of superlative degree by tabulation mean.

\begin{tabular}{|l|l|c|c|c|c|c|c|c|}
\hline \multirow{2}{*}{ No. } & \multirow{2}{*}{$\begin{array}{l}\text { Name Of } \\
\text { Students }\end{array}$} & \multicolumn{5}{|c|}{ Superlative Degree } & \multirow{2}{*}{$\begin{array}{c}\text { Score } \\
\text { of } \\
\text { Test }\end{array}$} \\
\cline { 3 - 9 } & & Worst & Best & Farthest & Least & Most & Eldest & \\
\hline 1. & Student A & 3 & 1 & 0 & 0 & 0 & 2 & 33 \\
\hline 2. & Student B & 3 & 1 & 0 & 0 & 0 & 2 & 33 \\
\hline 3. & Student C & 1 & 0 & 0 & 0 & 0 & 2 & 17 \\
\hline 4. & Student D & 0 & 0 & 0 & 0 & 0 & 2 & 11 \\
\hline 5. & Student E & 1 & 3 & 1 & 0 & 2 & 1 & 44 \\
\hline 6. & Student F & 1 & 0 & 0 & 0 & 0 & 2 & 17 \\
\hline 7. & Student G & 1 & 0 & 0 & 0 & 0 & 2 & 17 \\
\hline 8. & Student H & 0 & 3 & 2 & 0 & 0 & 3 & 44 \\
\hline 9. & Student I & 2 & 0 & 0 & 0 & 1 & 2 & 28 \\
\hline 10. & Student J & 1 & 3 & 1 & 0 & 2 & 2 & 50 \\
\hline 11. & Student K & 1 & 0 & 0 & 0 & 0 & 2 & 17 \\
\hline 12. & Student L & 3 & 2 & 2 & 2 & 3 & 1 & 72 \\
\hline $\begin{array}{r}\text { Store of } \\
\text { Superlative } \\
\text { Degre } \\
\text { e }\end{array}$ & $65 \%$ & $50 \%$ & $23 \%$ & $8 \%$ & $31 \%$ & $89 \%$ & $32 \%$ \\
\hline
\end{tabular}


INTERACTION:Jurnal Pendidikan Bahasa: Vol. 6, No. 2: Oktober 2019

ISSN: 2406-9558; E-ISSN: 2406-9566

The table above describes students ability in superlative degree speciffictly on worst $=65 \%$, best $=50 \%$, farthest $=23 \%$, least $=8 \%$, most $=31 \%$, Eldest $=89 \%$. In overall, can be seen their mean score of superlative degree $=32 \%$. It means that their ability in superlative degree was very bad. From amount of total students at Madrasah Aliyah Muhammadiyah Aimas were twenty persons(20), but total of the students followed examiner this research was twelleve (12) person. From both of the data above can be seen the students ability on comparison degree was still bad that was $45 \%$ for comparative degree and $32 \%$ for the superlative degree.

\section{CONCLUSION}

In collecting the data, the writer used descriptive methode. Comparison degree is a compare between one noun with other noun, one people by other people, and etc. In comparison degree, the writer focuss to discuss about using irregular form on comparison degree. The writer want to see the students ability on comparison degree in irregular form of the first grade at Madrasah Aliyah Muhammadiyah Aimas. In investigate research instrument the writer used was written test that was multiplechooise. The test consisted of 36 numbers, 18 numbers discuss about comparative degree and 18 number discuss about superlative degree. By this 36 number of test.

After the writer got the data of the students, the writer investgated the data by system manual by multiplying the total gain with $100 \%$ and deviding the result with the amount of total score to get the score (Score $=\mathrm{F} \times 100 \% / \mathrm{N})$. through the formula, the writer saw the score presentage of the students on comparative degree was $83 \%$ and superlative degree was $72 \%$. Mean of score from all the students were comparative degree $47 \%$ and superlative degree $32 \%$. These were included in bad and very bad category.

\section{REFERENCE}

Arikunto, Suharsimi.Penelitian Tindakan Kelas,Jakarta: Bumi Aksara, 2009. Dasar-dasar Evaluasi Pendidikan,Jakarta: Bumi Aksara, 2009.

Ari Susanti. (2011), An Analysis On Students' Mastery Of Degree Comparison (Case Study at Second Gray VIII 10) Of SMP Negeri 3 TangeranSelatan.Tangerang Selatan: SMP Negeri 3 Tangerang Selatan.

Bailey, Kathleen M. Learning about Language Assessment: Dillemas, Decisions, and Direction, London: Heinle \& Heinle Publisher, 1998.

Burns,Anne.Collaborative Action Research for English Language Teachers,NewYork: Cambridge University press, 1999.

Celce-Murcia, Marriane and DianeLarsen-Freeman.The Grammar Book: AnESL/EFL Teacher's Course, USA: Heinle \& Heinle Publisher, Inc, 1999.

Djamarah,Syaiful Bahriand Aswan Zain. Strategi Belajar Mengajar, Jakarta: PT Rineka Cipta, 2006. 
INTERACTION:Jurnal Pendidikan Bahasa: Vol. 6, No. 2: Oktober 2019 ISSN: 2406-9558; E-ISSN: 2406-9566

Fatmawati. (2010), The Analysis On Students' Difficulies In Learning Degrees Of Comparison. Ciputat: SMP Dua Mei Ciputat.

Fernando. (2010), Improving Students Ability In Forming Degree of Comparison By Using Subtitition Drills (A Classroom Action Research at The First Grade of Accountancy Class at Vocational School of Bangun Nusantara 2, Cipondoh, Tangerang). Tangerang: Vocational School of Bangun Nusantara 2, Cipondoh, Tangerang

Gorell and Laird. Modern English Handbook, New Jersey: Prentice Hall Inc, 1964.

Hewings, Martin. Advanced Grammar in Use, United Kingdom: Cambridge University Press, 2005.

Kunandar. Langkah Mudah Penelitian Tindakan Kelas Sebagai Pengembangan Profesi Guru, Jakarta:PT Raja Grafindo Persada, 2008.

Kusuma, Wijayaand Dedi Dwitagama.Mengenal Penelitian Tindakan Kelas, Jakarta: PT Indeks, 2009.

Nunan, David. Research Method in Language Learning, New York: Cambridge University Press, 1992.

Nuttall, C E. English Language Units: Comparison of Adjectives and Adverbs,London: Longman Group Ltd, 1971.

Oller, John W. Language Test at School, London: Longman Group Limited, 1979.

Parrot, Martin.Grammar for English Language Teachers, USA: Cambridge University Press, 2000.

Richard, Jack C and David Nunan. Second Language Teacher Education, New York:Cambridge University Press, 1990.

Sudijono, Anas. Pengantar Statistis Pendidikan, Jakarta: PT Raja Grafindo Persada, 2008.

Sudjana. Metode Statistika, Bandung: PT. Tarsito, 2002.

Thomson, A.J.and A. V Martinet. A Practical English Grammar, New York: Oxford University Press, 1986.

Thornbury, Scott. How to Teach Grammar, England: Pearson Education, 1999.

Ur, Penny. A Course in Language Teaching, Cambridge: Cambridge University Press, 1996.

.Grammar Practice Activities;A Practical Guide for Teacher, New York:Cambridge University Press, 1988.

Wallace, Michael J. Action Research for Language Teachers, Cambridge: CambridgeUniversity Press, 2006.

Wiriaatmadja, Rochiati. Metode Penelitian Tindakan Kelas, Bandung: PT. RemajaRosdakarya, 2009.

Zandvoort R.W. and J.AVan Ek. A Handbook of English Grammar, London:Longman Group Limited, 1980 